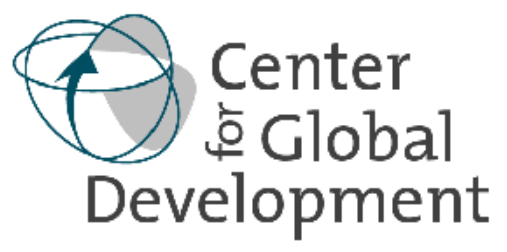

Feloruary 2008

\title{
Crossroads at Mmamabula: Will the World Bank Choose the Clean Energy Path? \\ By David Wheeler
}

\begin{abstract}
At the recent UN climate change conference in Bali, UN Secretary General Ban Ki-moon called for a revolutionary change in the world's energy mix to minimize the risk of catastrophic global heating. This paper explores the implications for the World Bank and other donor institutions, employing proposed Bank financing of the Mmamabula coal-fired power project in Botswana as an illustrative case. Using the latest estimates of generating costs for coal-fired and low-carbon power options, I compute the $\mathrm{CO} 2$ accounting charges that would promote switching to the low-carbon options. In all cases, I find that that the switching charges are at the low end of the range that is compatible with safe atmospheric limits on carbon loading. Among the low-carbon options that I have considered for Botswana, solar thermal power seems to dominate carbon capture and storage.

My results suggest that the World Bank and other donor institutions will adopt a transformational energy policy if they use appropriate accounting charges for carbon emissions. The Mmamabula example indicates that this approach will select low-carbon options in many cases, and grants from the Bank's Clean Technology Fund and other sources can finance the market-cost gap between clean and fossil-fired technologies. Clean energy projects should proliferate, as donors learn about the new approach and more funds are devoted to meeting the global emissions reduction mandate.
\end{abstract}

The Center for Global Development is an independent think tank that works to reduce global poverty and inequality through rigorous research and active engagement with the policy community. Use and dissemination of this Working Paper is encouraged, however reproduced copies may not be used for commercial purposes. Further usage is permitted under the terms of the Creative Commons License. The views expressed in this paper are those of the author and should not be attributed to the directors or funders of the Center for Global Development.

www.cgdev.org 


\title{
Crossroads at Mmamabula: \\ Will the World Bank Choose the Clean Energy Path?
}

\author{
David Wheeler* \\ Center for Global Development \\ February, 2008
}

* The author is a Senior Fellow at CGD. For useful comments and suggestions, many thanks to Kevin Ummel, Vijaya Ramachandran, Kirk Hamilton, Nancy Birdsall and Lawrence MacDonald. I am responsible for remaining errors of fact and interpretation. 


\section{Introduction}

At the UN's December climate change conference in Bali, Indonesia, Secretary General Ban Ki-moon declared a planetary emergency:

"The situation is so desperately serious that any delay could push us past the tipping point, beyond which the ecological, financial and human costs would increase dramatically ... We are at a crossroad. One path leads to a comprehensive climate change agreement, the other to oblivion. The choice is clear.” (Spiegel, 2007)

The science supports the Secretary General's assertion. In a December address to the American Geophysical Union, James Hansen, Director of NASA's Goddard Institute for Space Studies, summarized recent findings and suggested that the critical tipping point may be at an atmospheric CO2 concentration around 350 parts per million volume (ppm) (Inman, 2007). This is a significant retrenchment from the previous consensus threshold of 450 ppm. The news is doubly alarming because we are already beyond this limit: The current atmospheric CO2 concentration is around 386 ppm, and rising fast.

These developments have powerful implications for the World Bank Group, and particularly for its future energy projects. The Secretary General’s invocation of a crossroads implies a sharp break with past practice and an immediate commitment to clean energy development. However, the Bank Group continues to support construction of coal-fired plants as if nothing has changed. This paper focuses particularly on the latest proposed venture, a huge coal-fired plant to be fueled by the Mmamabula coal field in Botswana. The project is a tender from the private sector, treated as a business opportunity by the Bank with only cursory attention to four critical strategic questions: What are Botswana's options for large-scale power development? What are their comparative costs? How should their carbon emissions be incorporated into the cost 
assessment? How can the Bank group use this information to accelerate the transition to clean power in developing countries?

In this paper, I address the four questions in a comparative cost analysis for several coal-fired and low-carbon power investment options. Although Mmamabula provides the immediate context, the analysis could apply equally well to multilateral or bilateral energy projects in many other developing countries. The remainder of the paper is organized as follows. Sections 2 and 3 introduce the proposed Mmamabula project and discuss the World Bank Group’s rationale for supporting coal-fired power plants. In Sections 4 and 5, I test this rationale by introducing carbon dioxide emissions charges into a cost comparison for coal-fired and low-carbon energy options. Section 6 discusses the policy implications of my results, while Section 7 provides a summary and conclusions.

\section{The Mmamabula Project}

Mmamabula is a large coal field in Botswana, $120 \mathrm{~km}$ north of the capital, Gabarone, and just west of the South African border. Holding over 3 billion tons of coal, it is sufficient to fuel a 3,600 Megawatt (MW) power plant for 40 years. CIC Energy Corporation, headquartered in the Caribbean, has the exploitation rights and intends to build a 2,100-2,400 MW facility (CIC, 2008). If the plant employs high-efficiency coal combustion technology, it will emit 17-19 million tons of CO2 per year, and 680-760 million tons during a 40-year operating lifetime. ${ }^{1}$ This enormous emissions volume will place Mmamabula in the top 150 global polluters among 25,000+ carbon-emitting power plants (CARMA, 2008). Nevertheless, the World Bank Group is seriously considering

1 This calculation assumes use of supercritical technology, 830 grams/kWh CO2 emissions intensity, and an $80 \%$ capacity utilization factor. For a detailed technical discussion, see MIT (2007). 
CIC’s invitation to participate in financing the project. The Group’s Multilateral Investment Guarantee Agency (MIGA) devotes a web page to Mmamabula (MIGA, 2008); CIC notes that the project design will meet World Bank environmental standards for coal-fired plants (CIC, 2008); and Bank officials have recently met to discuss participation. World Bank support would not be surprising, since the Bank Group’s International Finance Corporation (IFC) has been financing large coal-fired plants in India (Wheeler, 2008; IFC, 2008a).

All this despite the UN Secretary General's clear warning about an impending climate catastrophe. In fact, the World Bank's consideration of the Mmamabula project seems purely reactive, not strategic, since the tender originated with CIC Energy. If the Group decides to use scarce international resources to help finance coal-fired power from Mmamabula, it will undoubtedly use the IFC's rationale for supporting Tata Power Company's huge coal-fired Mundra plant in Gujarat, India:

"Due to [Mundra's] high energy efficiency of supercritical technology, the Clean Development Mechanism (CDM) Executive Board meeting (under UNFCCC's Kyoto Protocol) of September 2007 approved the eligibility of supercritical coalfired plants for carbon credit in developing countries, and the company is exploring an opportunity for the Project to be registered under CDM." (IFC, 2008b)

The CDM rationale for World Bank support of a supercritical coal-fired plant is that emissions from the plant (or a set of smaller plants with the same total capacity) would be even greater if it used subcritical technology with lower energy efficiency. ${ }^{2}$ Applying this logic to Mmamabula, the World Bank would use scarce international resources to pay CIC Energy, a private firm, for adopting supercritical technology and polluting less than it would otherwise (by using a cheaper, more polluting technology).

2 See MIT (2007) for a detailed discussion of coal combustion technologies. 


\section{Problems with the Rationale}

The logic of this rationale reflects the 1997 Kyoto Protocol, which specified binding emissions limits only for rich countries, leaving poor countries free to overcome poverty without worrying about carbon emissions. In 1997, the prevailing view held that richcountry carbon emissions had caused the climate problem, and rich countries should therefore solve it. Unfortunately, that view has now been rendered obsolete by the rapid growth of developing-country emissions. In a recent paper, Wheeler and Ummel (2007) show that emissions growth from developing countries would have propelled the atmospheric CO2 concentration to a crisis level by 2025, even if rich countries had never emitted a ton of CO2. The stark reality is that uncontrolled emissions from either the North or the South will be enough to produce a climate catastrophe. And, as I noted in the introduction, the urgency is compounded by the current atmospheric CO2 concentration level, $386 \mathrm{ppm}$, because recent scientific findings suggest that the safe concentration level is around $350 \mathrm{ppm}^{3}$

If we are already past the safe limit for atmospheric carbon loading, then it obviously makes no sense for the World Bank and other public lending agencies to treat carbon emissions as costless. In fact, World Bank Group subsidies and CDM credits for supercritical coal-fired plants do reflect an implicit accounting charge for extra CO2 emissions from scale-equivalent subcritical plants operated under developing-country conditions. The subsidies and credits are justified by the presumption that subcritical technology is cheaper, so private firms will choose it without countervailing incentives.

\footnotetext{
3 See also Hoene (2006) for evidence that the critical threshold lies below 450 ppm.
} 
This rationale suffers from two serious problems. The first is posed by the assumption that subcritical technology is less costly. The World Bank itself has just published a cost comparison of power options for developing countries which concludes that supercritical plants have lower delivered-electricity costs than subcritical plants (ESMAP, 2007). ${ }^{4}$ MIT’s recent landmark study of coal technologies draws the same conclusion (MIT, 2007). Taken at face value, these findings eliminate the rationale for Bank or CDM subsidies for supercritical technology, because profit-maximizing firms would prefer it to subcritical technology in any case.

The second problem is more fundamental, with more far-reaching implications. The Bank and the CDM Board justify carbon credits for supercritical plants using a presumably-cheaper coal-fired technology as the baseline for comparison. Since carbon emissions from supercritical plants remain huge, such credits only make sense if lowcarbon alternatives are too costly for realistic consideration. But the appropriate accounting cost is social cost in this context, because the international community is footing the bill. And the social costs of high- and low-carbon alternatives cannot be assessed without specifying an appropriate unit charge for carbon emissions. I will provide such an assessment after introducing low-carbon alternatives for Mmamabula that are technically feasible.

\section{Low-Carbon Alternatives}

One option for the Bank would be grant financing of carbon capture and storage (CCS) for the Mmamabula project through its donor-funded Investment Framework for Clean Energy and Development, which gives priority to African energy projects (World

4 ESMAP (2007), Table 4.5. The comparison of levelized costs for 500 MW units yields a generating cost of $4.33 \mathrm{US} \$ / \mathrm{kWh}$ for subcritical and $4.29 \mathrm{k} / \mathrm{kWh}$ for supercritical. Levelized cost is the constant-dollar electricity price required to recover capital costs, O\&M and fuel costs over the life of a power plant. 
Bank, 2006). After a lengthy period of engineering development, CCS is ready for largescale pilot applications. If successfully implemented, CCS will drastically reduce carbon emissions from modern high-efficiency coal-fired plants (MIT, 2007). Feasibility for Mmamabula would require access to large underground storage capacity, possibly at a previously-mined site. The risk of potential large-scale leakage would also have to be assessed. With grant financing available, Mmamabula might well be a useful large-scale pilot for CCS, but there is no sign that the Bank has seriously considered this option.

Botswana also has enormous solar energy potential, as documented by a recent World Bank study (Buys, 2007). Recent developments in solar thermal energy technology make it feasible to consider this zero-emissions option for large-scale baseload power provision (Mills, 2007). Unlike solar photovoltaics, which convert sunlight directly to electricity at low efficiency, solar thermal installations use heat from concentrated sunlight to drive conventional, high-efficiency generators. Since their heat is easily stored, solar thermal installations can also deliver continuous power around the clock. Potential energy from these systems is enormous. In the US, for example, total current electric power generation could be provided by solar thermal arrays in a square of Nevada desert about 90 miles on a side (Mills, 2007; Khosla, 2006; Figure 1). An equivalent array in Botswana, capable of producing 10 times Africa's total current electricity output, would occupy less than $4 \%$ of the land in this sparsely-populated country.

\section{Assessing the Options}

To assess Botswana’s options for large-scale power investment, I use comparative cost estimates for six technologies. Two employ high-efficiency coal combustion: 
supercritical (SC) and integrated gasification combined-cycle (IGCC); two combine these technologies with carbon capture and storage (CCS); and two generate solar thermal power: parabolic trough (PT) arrays and compact linear Fresnel reflector (CLFR) arrays. ${ }^{5}$ I assess the options in the following steps. First, I identify the latest-available estimates of levelized energy-delivery costs and CO2 emissions intensities for the six technologies. ${ }^{6}$ Then, using SC and IGCC as the baselines for comparison, I compute the CO2 emissions charges at which cost-minimizing producers would switch to the CCS and solar thermal technologies because they would be less costly than the baselines. To assess the low-carbon options from the perspective of the World Bank's social mandate, I compare their switching costs with a range of current estimates for appropriate $\mathrm{CO} 2$ emissions charges. Finally, I consider factors other than CO2 charges that are relevant for assessing the full social costs of the six options. I'll begin with a discussion of appropriate CO2 charges.

\subsection{Current CO2 Charge Estimates}

Nordhaus (2007a), Stern (2006) and others have estimated the CO2 charges that are consistent with different levels of emissions control. The underlying economic logic supports a charge that rises over time. At present, most damages from global warming are in the relatively distant future and there are plentiful high-return opportunities for conventional investment. Investment should become more intensive in emissions reduction as climate-related damage rises, and rising charges will provide the requisite incentive to reduce emissions. The optimal "ramp" for charges depends on factors such

\footnotetext{
${ }^{5}$ For discussion of SC and IGCC, see MIT (2007); for solar thermal power technologies, see Ausra (2008), Brakmann (2005), Khosla (2007) and ESMAP (2007).

${ }^{6}$ Levelized cost is the constant-dollar electricity price required to recover capital costs, O\&M and fuel costs over the life of a power plant.
} 
as the discount rate, abatement costs, the potential for technological learning, and the scale and irreversibility of damage from climate change (Nordhaus, 2007b). Since these factors remain contentious, it is not surprising that different studies establish very different ramps. Nordhaus’ preferred path begins at about $\$ 8 /$ ton of CO2, rising to about $\$ 23 /$ ton by 2050. Stern’s initial charge is 10 times higher -- $\$ 82 /$ ton - and his ramp is steeper. ${ }^{7}$ IPCC IV (2007) cites a variety of studies whose results range from \$3/ton to \$95/ton.

Although Nordhaus and Stern claim optimality for their preferred CO2 charges, both use assumptions that are inconsistent with the current consensus on scientific safe limits for atmospheric carbon loading. Nordhaus’ optimal charge path, beginning at \$8/ton of CO2, is consistent with an atmospheric CO2 concentration limit of $700 \mathrm{ppm}$. Stern’s optimal initial charge, $\$ 82 /$ ton, is consistent with a limit of $550 \mathrm{ppm}$. In contrast, as previously noted, the current scientific consensus is falling from 450 ppm toward 350 ppm. By implication, even Stern’s initial charge appears modest. In any case, the Nordhaus - Stern charge range provides a useful benchmark for judging the results of my assessment of high- and low-carbon options..

\subsection{Switching Charges for Low-Carbon Technologies}

I estimate the accounting charges for $\mathrm{CO} 2$ emissions at which solar thermal and CCS technologies have lower levelized electricity costs (LEC’s) than high-efficiency coal-fired options. The switching charge is the charge rate $\mathrm{r}^{*}$ (\$/ton of CO2) that solves equation $(1):^{8}$

\footnotetext{
${ }^{7}$ For useful discussion, see Weitzman (2007).

${ }^{8}$ In equation (1), the multiplier (1/10) converts $\$ /$ MWh to $\$ / k W h([100 \$ / \$] /[1000 \mathrm{kWh} / \mathrm{MWh}])$
} 
(1) $l_{C}+\left(\frac{1}{10}\right) r^{*} t_{C}=l_{L}+\left(\frac{1}{10}\right) r^{*} t_{L}$

where $\mathrm{l}_{\mathrm{C}}=$ levelized electricity cost $(\$ / \mathrm{kWh})$ of the non-CCS coal-fired option

$\mathrm{l}_{\mathrm{L}}=$ levelized electricity cost $(\$ / \mathrm{kWh})$ of the low-carbon option

$\mathrm{r}^{*}=\mathrm{CO} 2$ charge rate in $\$ /$ ton

$\mathrm{t}_{\mathrm{C}}=\mathrm{CO} 2$ emissions intensity (tons/MWh) of the non-CCS coal-fired option

$\mathrm{t}_{\mathrm{L}}=\mathrm{CO} 2$ emissons intensity (tons/MWh) of the low-carbon option.

The switching CO2 charge $\mathrm{r}^{*}$ is therefore

$$
r^{*}=\frac{10\left(l_{C}-l_{L}\right)}{t_{C}-t_{L}}
$$

To compute the switching charges in Table 1 , I use estimates of $l_{C}$ from MIT (2007) and ESMAP (2007) for the SC and IGCC coal-fired options; $t_{C}$ and $t_{L}$ from MIT (2007) for SC, IGCC, SC/CCS and IGCC/CCS; and $\mathrm{l}_{\mathrm{L}}$ for PT solar thermal and CLFR solar thermal from Barringer (2007) and Mills (2007), respectively. ${ }^{9}$

Table 1 presents the supporting data and switching charge solutions for all four lowcarbon options when they are compared with the two coal-fired options. Between the two solar thermal options, CLFR does much better than PT because its levelized electricity cost is much lower: $7.8 \mathrm{\$} / \mathrm{kWh}$ vs. $10 \mathrm{\$} / \mathrm{kWh}$. When compared with the two coal-fired options, using both MIT and ESMAP estimates, CLFR solar thermal is preferable to SC at an average CO2 charge rate of \$35.50/ton, and preferable to IGCC at \$29/ton. PT solar thermal is preferable to SC at an average CO2 charge rate of \$60/ton, and preferable to IGCC at \$53/ton.

Between the two carbon capture and storage (CCS) options, IGCC with CCS does better than SC with CCS because its levelized electricity cost is lower (6.52 $\mathrm{c} / \mathrm{kWh}$ vs.

\footnotetext{
${ }^{9} t_{L}=0$ for both solar thermal options; $t_{L}$ is small but non-zero for both CCS options. I have not used ESMAP's estimate for solar thermal power because its sole scale option (30 MW) does not capture the significant scale economies available in 500+ MW systems.
} 
$7.69 \mathrm{k} / \mathrm{kWh}$ ). When compared with the coal-fired options without CCS, IGCC/CCS is preferable to SC at an average CO2 charge rate of $\$ 21.50 /$ ton and preferable to IGCC at $\$ 15 /$ ton. SC/CCS is preferable to SC at $\$ 34.50 /$ ton and preferable to IGCC at $\$ 28 /$ ton.

To summarize, all the switching charges look quite reasonable - indeed conservative - in light of the $\mathrm{CO} 2$ charge discussion in the previous section. All are well below the Stern charge (\$82/ton of CO2), which is only consistent with a dangerous concentration level (550 ppm) in any case. Achieving $450 \mathrm{ppm}$ would require a much higher charge, and 350 ppm far higher still. However, extremely high charges are obviously not necessary to warrant switching away from coal-fired power. The leastcost, most environmentally benign option is CLFR solar thermal, which has cost parity with supercritical coal-fired power at $\$ 35.50 /$ ton for CO2. Among the low-carbon coalfired alternatives, the results support a switch from SC to IGCC with CCS. This achieves cost parity with conventional SC at a charge of only $\$ 21.50 /$ ton for CO2.

\subsection{Other Cost Factors}

A full social assessment would require consideration of several factors besides carbon charges. Solar thermal technology is pollution-free, but all coal-fired technologies (with and without CCS) produce potentially-dangerous local air pollutants (SO2, NOx, Mercury). Solar thermal facilities are powered by an inexhaustible free resource, while coal supplies are subject to price fluctuations. ${ }^{10}$ Stored carbon from CCS will have to be piped to an underground facility at some cost. In addition, it will undoubtedly carry a significant insurance cost because large, high-concentration $\mathrm{CO}_{2}$ releases could be quite dangerous. If I roughly incorporate these factors by subtracting

${ }^{10}$ This is true even for Mmamabula, a combined mining/power project, since the market opportunity cost of coal is the appropriate accounting price for the power component. 
$1 \mathrm{~d} / \mathrm{kWh}$ from the levelized cost of solar thermal power, the calculus becomes even more favorable for solar (Table 2). The switching charges for CLFR solar become much lower than the charges for supercritical coal with CCS, and approximately equal to the charges for IGCC coal with CCS.

\section{Policy Implications}

These results have strong implications for Mmamabula and similar projects considered by the World Bank and other donor-financed institutions. Using the latest estimates for levelized electricity generation costs, I find that all four low-carbon technologies are lower-cost than supercritical or IGCC coal-fired options for CO2 charges at the low end of the range consistent with safe atmospheric carbon loading. Since the low-carbon options are also in the initial segments of their learning curves, it is entirely possible that volume production will reduce their levelized generating costs to market parity with coal-fired technologies without any charges for carbon emissions. Among the low-carbon options, solar thermal seems likely to dominate CCS because its fully-accounted costs will be significantly lower.

Several policy recommendations immediately follow for the World Bank Group. First, adopt an explicit carbon accounting charge that can be defended as consistent with atmospheric safe limits for carbon loading. In view of the current scientific consensus, it will be very surprising if this is below $\$ 50 /$ ton of CO2. Second, add this charge to levelized cost estimates for all proposed fossil-fuel energy projects (oil and gas as well as coal), with and without CCS. Costs should also be adjusted for local pollution factors, fuel supply risks and risk insurance. Third, compare the results with levelized generating costs for locally-feasible zero-emissions options, with an appropriate learning-curve 
adjustment. This adjustment is critical for huge institutions like the Bank, which can generate aggregate global demand large enough to affect learning curves.

As the Mmamabula example has shown, there can be little doubt that adoption of these measures would radically alter the carbon intensity of power projects financed by the World Bank and other donor institutions. In the beginning, additional subsidies might be needed to induce clients to borrow for low-carbon projects. However, client interest should increase as Bank programs demonstrate the viability of large-scale low-carbon energy systems that have no local environmental impacts, no energy supply risks, and no liability insurance requirements.

Given the urgency of the climate crisis, the World Band and other donor institutions should adopt such measures immediately. If the cost assessment is done right, the grant component of each loan for a low-carbon project should be determined by the difference in fully-accounted, levelized market costs between the best low-carbon option and the best fossil-fired option. Loan volume will be initially constrained by currently-available grant funds. ${ }^{11}$ However, funding should increase steadily as the benefits of the new policy become evident to donors, and as international pressure for carbon emissions reduction spurs interest in clean technologies. Increased demand for low-carbon technologies will also promote learning-curve effects, narrowing the market-cost gap between fossil-fired and low-carbon technologies.

\section{Summary and Conclusions}

At the recent UN climate change conference in Bali, UN Secretary General Ban Kimoon called for a revolutionary change in the world's energy mix to minimize the risk of

${ }^{11}$ In February, 2008, the Finance Ministers of the US, UK and Japan introduced a Clean Technology Fund that will be administered by the World Bank. The initial US contribution was $\$ 2$ billion (Paulson, Darling and Nukaga, 2008). 
catastrophic global heating. In this paper, I have explored the implications for the World Bank and other donor institutions, employing the proposed Mmamabula coal-fired power plant in Botswana as an illustrative case. Using the latest estimates of levelized generating costs for coal-fired and low-carbon power options, I have computed the CO2 accounting charges that would promote switching to the low-carbon options. In all cases, I find that that the switching charges are at the low end of the range that is compatible with safe atmospheric limits on carbon loading. Among the low-carbon options that I have considered for Botswana, solar thermal power seems to dominate carbon capture and storage.

In the energy sector, at least, revolutionary change seems attainable for the World Bank and other donor institutions at feasible cost. The primary requirement is renewed attention to energy project analysis, using fully-accounted levelized energy costs and appropriate accounting charges for carbon emissions. The Mmamabula example suggests that this approach will select low-carbon options in many cases, and grants from the World Bank’s Clean Technology Fund and other sources can finance the market-cost gap between these technologies and fossil-fired options. Clean energy projects should proliferate, as donors learn about the new approach and more funds are devoted to meeting the global emissions reduction mandate. 


\section{References}

Ausra. 2008. An Introduction to Solar Thermal Electric Power. Available online at http://www.ausra.com/pdfs/SolarThermal101_final.pdf.

Barringer, Felicity and Matthew Wald. 2007. "PG\&E to buy solar power produced by mirrors in the Mojave.” International Herald Tribune. July 25. Available online at http://www.iht.com/articles/2007/07/25/business/solar.php.

Brakmann, Georg, Rainer Aringhoff, Michael Geyer and Sven Teske. 2005. Concentrated Solar Thermal Power - Now! Greenpeace. Available online at http://www.greenpeace.org/international/press/reports/Concentrated-Solar-ThermalPower.

Buys, Piet, Uwe Deichmann, Craig Meisner, Thao Ton That and David Wheeler. 2007. "Country Stakes in Climate Change Negotiations: Two Dimensions of Vulnerability." World Bank Policy Research Working Paper No. WPS 4300. Available online at http://econ.worldbank.org/external/default/main?pagePK=64165259\&theSitePK=469372 $\underline{\text { \&piPK}=64165421 \& \text { menuPK=64166093\&entityID=000158349_20070802104550. }}$.

CARMA (Carbon Monitoring for Action). 2008. Future global power plant rankings by CO2 emissions volume. Center for Global Development. Available online at http://carma.org/dig/show/energy+plant\#top.

CIC. 2008. CIC Energy Company Overview. Available online at http://www.cicenergycorp.com/corporate_information/company_overview/.

ESMAP (Energy Sector Management Assistance Program, World Bank). 2007. Technical and Economic Assessment of Off-grid, Mini-grid and Grid Electrification Technologies, ESMAP Technical Paper 121/07, December. Available online at http://siteresources.worldbank.org/EXTENERGY/Resources/3368051157034157861/ElectrificationAssessmentRptSummaryFINAL17May07.pdf.

Hoehne, N. 2006. "What is next after the Kyoto Protocol? Assessment of Options for International Climate Policy Post 2012.” Techne Press, Amsterdam, May.

IFC (International Finance Corporation). 2008a. "Lanco Amarkantak Thermal Power Station." Available online at http://www.ifc.org/IFCExt/spiwebsite1.nsf/0/c126975a64d3306e852572a0004807bd?Op enDocument.

IFC (International Finance Corporation). 2008b. “Tata Ultra Mega: Environmental \& Social Review Summary.” Available online at http://www.ifc.org/IFCExt/spiwebsite1.nsf/f451ebbe34a9a8ca85256a550073ff10/4d8d80 e1d8965a7e852573a00079518b?OpenDocument. 
IPCC IV (Intergovernmental Panel on Climate Change). 2007. Fourth Assessment Report. Available online at http://www.ipcc.ch.

Inman, Mason. 2007. “Global Warming ‘Tipping Points’ Reached, Scientist Says.” National Geographic News. December 14. Available online at http://news.nationalgeographic.com/news/2007/12/071214-tipping-points.html.

Khosla, Vinod. 2007. The War on Coal. Available online at http://www.khoslaventures.com/presentations/CoalThinkOutsidethePits.pdf.

Khosla, Vinod and John O’Donnell. 2006. “Solar Flare: Making Coal Obsolete.” Available online at http://www.khoslaventures.com/presentations/solarflare_final.ppt.

MIGA (Multilateral Investment Guarantee Agency). 2008. Mmamabula Energy Project Botswana. Available online at (http://www.fdi.net/documents/WorldBank/databases/botswana/Mmamabula_BotswanaII .pdf).

Mills, David and Rob Morgan. 2007. "Solar Thermal Power as the Plausible Basis of Grid Supply,” Presented to the International Solar Energy Society World Congress.

Beijing, China. Sept. 19. Available online at http://www.ausra.com/pdfs/T_1_1_David_Mills_2049.pdf.

Mining Review Africa. 2005. “Botswana on the cusp of massive coal project.” Issue 6. Available online at http://www.miningreview.com/archive/mra_6_2005/pdf/18-21.pdf.

MIT. 2007. The Future of Coal: Options for a Carbon-Constrained World. Cambridge, Massachusetts. Available online at http://web.mit.edu/coal/.

Nordhaus, William. 2007a. “The Challenge of Global Warming: Economic Models and Environmental Policy.” Dept. of Economics, Yale University, July 24. Available online at http://nordhaus.econ.yale.edu/dice_mss_072407_all.pdf.

Nordhaus, William. 2007b. "Critical Assumptions in the Stern Review on Climate Change.” Science. Vol. 317, July 13. pp. 201-202. Available online at http://www.sciencemag.org/cgi/content/full/317/5835/201.

Paulson, Henry, Alistair Darling and Fukushiro Nukaga. 2008. "Financial bridge from dirty to clean technology.” Financial Times. February 8. Available online at http://www.ft.com/cms/s/0/43975af2-d5e7-11dc-bbb2-0000779fd2ac.html.

Spiegel. 2007. “Stark Words at Bali Conference.” December 12. Available online at http://www.spiegel.de/international/world/0,1518,522929,00.html. 
Stern, Nicholas, et al. 2006. Stern Review on the economics of climate change. Available online at http://www.hm-

treasury.gov.uk/independent_reviews/stern_review_economics_climate_change/sternrevi ew index.cfm.

Weitzman, Martin. 2007. "A Review of The Stern Review on the Economics of Climate Change.” Journal of Economic Literature, Vol. XLV (September 2007), pp. 703-724. Available online at http://www.atypon-link.com/AEAP/doi/abs/10.1257/jel.45.3.703.

Wheeler, David and Kevin Ummel. 2007. “Another Inconvenient Truth: A CarbonIntensive South Faces Environmental Disaster, No Matter What the North Does.” Center for Global Development Working Paper No. 134. December. Available online at http://www.cgdev.org/content/publications/detail/14947.

Wheeler, David. 2008. "CARMA Watch: Red Light for The World Bank Group on CoalFired Power." Center for Global Development. Available online at http://blogs.cgdev.org/globaldevelopment/2008/01/carma_watch_red_light_for_the.php.

World Bank. 2006. An Investment Framework for Clean Energy and Development. Available online at http://siteresources.worldbank.org/DEVCOMMINT/Documentation/21046509/DC20060012(E)-CleanEnergy.pdf. 
Table 1: Technology-Switching CO2 Charges (\$US/Ton)

\begin{tabular}{|c|c|c|c|c|c|c|c|}
\hline & & & & \multicolumn{4}{|c|}{ Switching CO2 Charge (\$/Ton) } \\
\hline & & & & \multicolumn{2}{|c|}{ Solar Thermal } & \multicolumn{2}{|c|}{$\begin{array}{l}\text { Coal with Carbon } \\
\text { Capture \& Storage }\end{array}$} \\
\hline Technology & $\begin{array}{l}\text { Generating } \\
\text { Capacity } \\
\text { (MW) }\end{array}$ & $\begin{array}{c}\text { Generation } \\
\text { Cost } \\
(\$ / k W h)\end{array}$ & $\begin{array}{l}\text { Tons } \\
\mathrm{CO} 2 / \\
\mathrm{MWh}\end{array}$ & $\begin{array}{c}(1) \\
\text { CLFR }^{a}\end{array}$ & $\begin{array}{l}\text { (2) } \\
\mathrm{PT}^{\mathrm{b}}\end{array}$ & $\begin{array}{l}(3) \\
S^{c}\end{array}$ & $\begin{array}{c}(4) \\
I^{\prime G C C}{ }^{d}\end{array}$ \\
\hline Coal SC (WB) ${ }^{\mathrm{e}}$ & 500 & 4.29 & 0.913 & 38 & 63 & 37 & 24 \\
\hline Coal SC (MIT) ${ }^{f}$ & 500 & 4.78 & 0.913 & 33 & 57 & 32 & 19 \\
\hline Coal IGCC (WB) & 500 & 5.14 & 0.915 & 29 & 53 & 28 & 15 \\
\hline Coal IGCC (MIT) & 500 & 5.13 & 0.915 & 29 & 53 & 28 & 15 \\
\hline Coal SC (MIT) w. CCS & 500 & 7.69 & 0.120 & & & & \\
\hline Coal IGCC (MIT) w. CCS & 500 & 6.52 & 0.112 & & & & \\
\hline Solar Thermal PT & 550 & 10.00 & 0.000 & & & & \\
\hline Solar Thermal CLFR & 700 & 7.80 & 0.000 & & & & \\
\hline
\end{tabular}

${ }^{a}$ CLFR: Compact Linear Fresnel Reflector: Levelized costs reported in Mills (2007)

${ }^{b}$ PT: Parabolic Trough: Commericial delivery price reported by Barringer (2007)

c SC: Supercritical Coal

d IGCC: Integrated Gasification Combined Cycle Coal

${ }^{\mathrm{e}}$ World Bank, ESMAP (2007)

${ }^{\mathrm{f}}$ MIT (2007)

Table 2: Technology-Switching CO2 Charges (\$US/Ton) With Solar Cost Adjustment

\begin{tabular}{|l|c|c|c|c|c|c|}
\hline & \multicolumn{5}{|c|}{ Switching CO2 Charge (\$/Ton) } \\
\hline & \multicolumn{2}{|c|}{ Solar Thermal CLFR } & \multicolumn{2}{c|}{ Solar Thermal PT } & \multicolumn{2}{c|}{ Coal-Fired with CCS } \\
\hline Technology & $\begin{array}{c}\text { CO2 } \\
\text { Charge } \\
\text { Only }\end{array}$ & $\begin{array}{c}\text { Including } \\
\text { Other Cost } \\
\text { Factors }\end{array}$ & $\begin{array}{c}\text { CO2 } \\
\text { Charge } \\
\text { Only }\end{array}$ & $\begin{array}{c}\text { Including } \\
\text { Other Cost } \\
\text { Factors }\end{array}$ & SC & IGCC \\
\hline Coal SC (WB) & 38 & 27 & 63 & 52 & 37 & 24 \\
\hline Coal SC (MIT) & 33 & 22 & 57 & 46 & 32 & 19 \\
\hline Coal IGCC (WB) & 29 & 18 & 53 & 42 & 28 & 15 \\
\hline Coal IGCC (MIT) & 29 & 18 & 53 & 42 & 28 & 15 \\
\hline
\end{tabular}


Figure 1: Nevada: Area Required to Power the US With Solar Thermal Energy

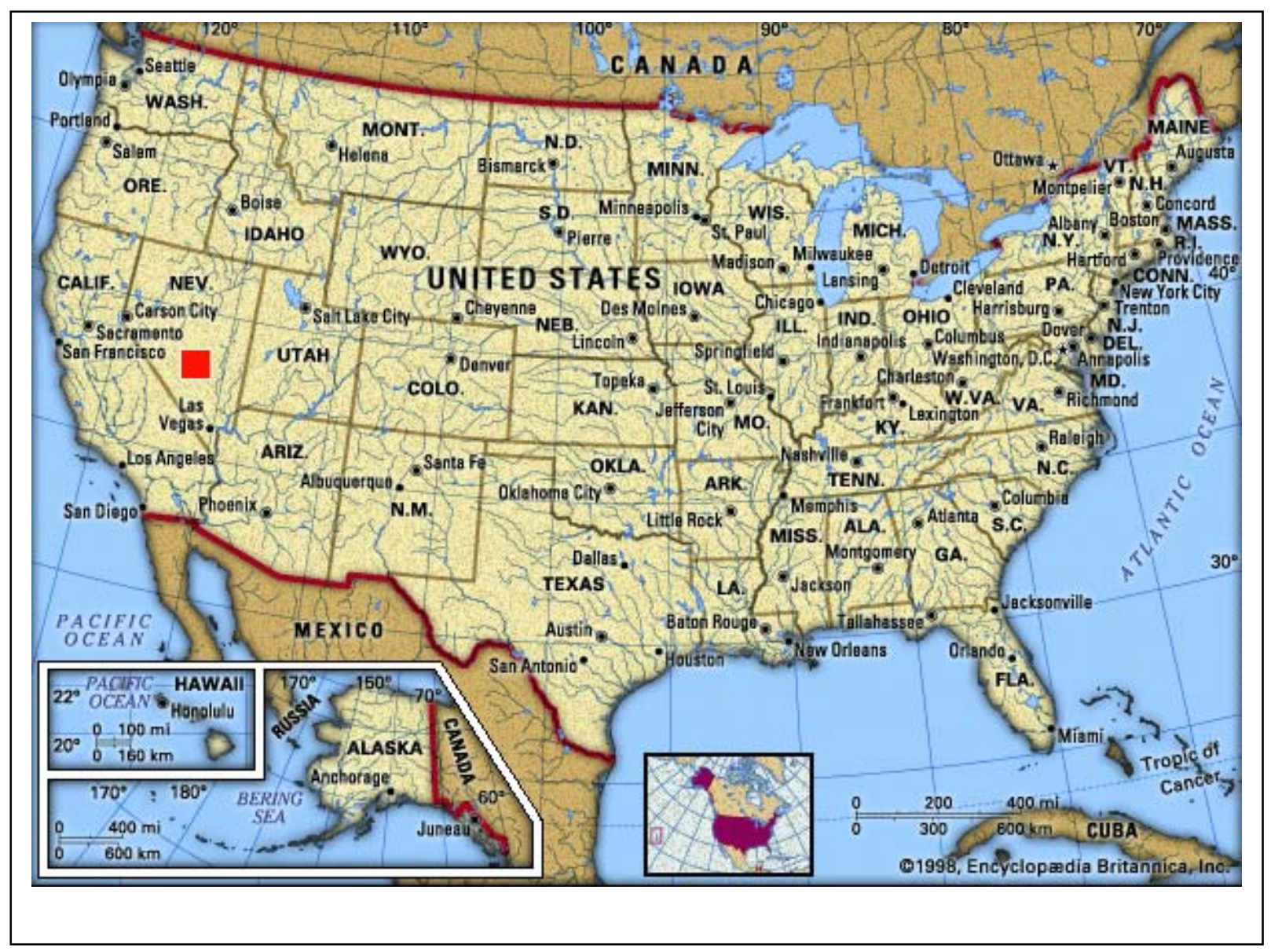

Source: Khosla and O’Donnell (2006) 